\title{
GLOBAL BECAUSE A \\ SLAVEHOLDING ORDER: AN \\ ANALYSIS OF THE URBAN DYNAMICS \\ OF RIO DE JANEIRO BETWEEN \\ 1790 AND 1815
}

(D) Ynaê Lopes dos Santos ${ }^{1 ; 2 ; 3}$

\section{ABSTRACT}

Rio de Janeiro stands out as one of the few cities in the Atlantic world that have managed to bring together characteristics so particular and at the same time revealing of the global dynamics that marked the last decades of the eighteenth century and the first fifty years of the next century. On the one hand, its political centrality became evident with its elevation to the thirst for colonial power (1763), its transformation into the Court of the Lusitanian Empire (1808) and its choice as the capital of the Brazilian Empire (1822), the portion "Versailles Tropical "Of Rio de Janeiro coexisted with a city that, in the words of an English traveler, more seemed the" heart of Africa "; with blacks and blacks of different origins, performing an innumerable number of activities that yielded to Rio de Janeiro the honorable title of the largest slave city in the Americas. More than harming foreign travelers unaccustomed to everyday slavery, or creating practices of "little Africa" in its territory, the strong presence of Africans and their descendants under the aegis of slavery reveals yet another facet of Rio de Janeiro: a locus of the world, in which identities, trajectories and senses of the city were in dispute. The purpose of this paper is precisely to understand the political, economic and social dynamics that characterized Rio de Janeiro as an important center of this Afro-Atlantic world its multiple voices between the years of 1790 and 1815 .

\section{KEYWORDS}

Rio de Janeiro - slavery - global city.

1 Universidade Federal Fluminense. Niterói - Rio de Janeiro - Brasil.

2 Professor of History of America at the UFF History Institute. E-mail: ynae.lopes.santos@gmail. com.

3 Translation by Mariana Dantas. 


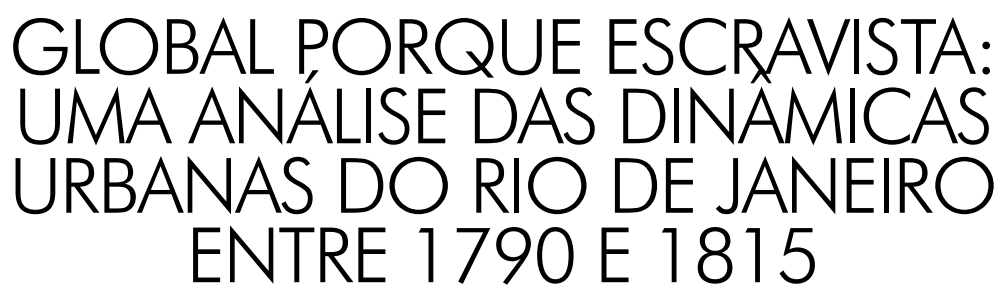

\section{RESUMO}

O Rio de Janeiro de destaca como uma das poucas cidades do Mundo Atlântico que conseguiram reunir características tão particulares e ao mesmo tempo tão reveladoras das dinâmicas globais que marcaram as últimas décadas do século XVIII e os primeiros cinquenta anos da centúria seguinte. Se por um lado sua centralidade política se fez notória com sua elevação à sede de poder colonial (1763), sua transformação em Corte do Império Lusitano (1808) e sua escolha como capital do Império do Brasil (1822), a porção "Versalhes Tropical" do Rio de Janeiro coexistiu com uma cidade que, nas palavras de um viajantes inglês, mais parecia o "coração da África"; com negros e negras de diferentes origens, executando um sem número de atividades que renderam ao Rio de Janeiro o título, pouco honroso, de maior cidade escravista das Américas. Mais do que chocar viajantes estrangeiros desacostumados com o cotidiano escravista, ou então criar práticas de "pequenas Áfricas" em seu território, a forte presença de africanos e seus descendentes sob a égide a escravidão revela mais uma faceta do Rio de Janeiro: um locus do mundo Afro-Atlântico, no qual identidades, trajetórias e sentidos de cidade estavam em disputa. O objetivo do presente trabalho é, justamente, compreender as dinâmicas políticas, econômicas e sociais que caracterizaram o Rio de Janeiro como importante centro deste mundo Afro-Atlântico e suas múltiplas vozes entre os anos de 1790 e 1815.

\section{PALAVRAS-CHAVE}

Rio de Janeiro - escravidão - cidade global. 


\section{$7 \mathrm{n}$ June of 1814, the Marquis of Aguiar sent a communication to the Count of Arcos in which he affirmed that:}

The Prince Regent's state of mind is calm in regards to the disorder provoked by the slaves of Manuel Ignácio's wharf because His Majesty has been reassured through this and other communications that He need not fear any fatal consequences or imminent danger from the aforementioned disorder, and all that has been said, beyond what Your Excellency has exposed on the matter, is exaggerated, false, and without warrant, and the same Lord has now intelligence of the order that Your Excellency dispatched to the General Criminal Judge to investigate, with the goal of learning, who are those who have spread such rumors, and I can assure Your Excellency that until the present moment no communication has reached the august presence of Hist Majesty, whether through the Secretary of State, representative of any corporation, or person employed in this captaincy, that complains of any omission on the part of Your Excellency in this matter ${ }^{4}$.

In principal, the authorities and inhabitants of the City of Rio de Janeiro, then the site of the court of the Portuguese Empire, had nothing to worry about in regard to the uprising of Manuel Ignácio's slaves-an event the Marquis of Aguiar insisted in calling a disorder. According to him, the incident not only posed no further threat to the City of Rio de Janeiro, it was just one of many incidents the authorities had to deal with in a city in which slavery dominated.

In reality, it was more important to investigate who was spreading rumors about the rebellious nature of the disorder than to investigate the event itself. Such was the case because, in the former viceroy's view, it was part of the responsibility of city governors to understand the dynamics that made the city function. It would be of no use, according to Aguiar, to forbid meetings by the slaves because of a fear of disorders. It was not only the case that many of these meetings were crucial to the well-being of the city, but also that excessive punishments and prohibitions were not synonymous with the good

4 BN. Documento II-33,24,29 - Oficio do Marquês de Aguiar, ao Conde dos Arcos. 
government of slaves. It was essential that the authorities recognize and differentiate entertainments that might lead, or not, slaves to commit crimes. It was a tenuous line that separated the two and, by underscoring that tenuousness, Aguiar revealed one of the most notable aspects of urban slavery.

Undoubtedly, the years during which the Marquis of Aguiar was Viceroy of Portuguese America (1801 to 1806) gave him sufficient experience to understand the extent to which slavery in Rio de Janeiro might seem ambiguous and contradictory to those who governed the city. The equation that balanced the city's dependence on slave labor with the imminent threat of a slave revolt was precarious and required knowledge and experience from those in power.

This ingenious equation applied not only to the well-being of the city and its slave population but was also relevant to the maintenance of the slave system in all of the Portuguese Empire during the so-called age of revolutions. It is in this sense, and based on recent contributions of works on global cities ${ }^{5}$, that this article proposes that the analysis of urban slavery in Rio de Janeiro elucidates the city's influence in the preservation and expansion of the transatlantic slave trade, as well as in the production of racial inequality and discrimination in the nineteenth-century Atlantic World. The article will focus on the period between 1791 and 1815, when the city experienced unique urban and political changes within the context of the history of the Americas, changes that were only possible thanks to the growth of its slave population.

\section{The arms on which all families rely}

Throughout his despotic government, the Count of Resende, viceroy of Brazil from 1790 to 1801, maintained his predecessors' prac-

5 This work engages the premise that global cities must be examined based on local dynamics as well as through the global networks they helped to create. DANTAS, M. HART, E. "Historical Aprroaches to researching the Global Urban”. In:HARRISON, J. HOYLER, M. Doing Global Urban Research. Los Angeles, SAGE, 2018. 
tice of using slaves (Africans and Brazilian-born) as the main workforce to implement urban improvements in the colonial capital. The Carioca Aqueduct - the city's main source of water - was covered and new streets were opened to keep up with the city's expansion in the direction of Lapa and Glória. The Viceroy also ordered the construction of an asylum for injured soldiers, installed street lighting (which used whale oil), and ordered the construction of the Moura Fountain in the immediacy of the Misericórdia neighborhood.

Slaves worked both in the construction and in the maintenance of these urban improvements. Streetlights and the Moura Fountain, for example, were of great importance to the city's everyday life, but required constant conservation from slave workers. As should be expected from a city where slaves represented forty percent of the urban population, the enslaved were also active in the commercial enterprises that animated Rio de Janeiro's internal economy. The work of historian Carlos Lima illustrates that reality. In his analysis of the trajectory of artisans in the colonial capital (shoemakers, tailors, barbers, carpenters, blacksmiths) he noticed a long list of slaves. Using post mortem inventories and city licenses, the author mapped a large number of urban commercial establishments, in particular those located in the city's main parishes ${ }^{6}$. Interestingly, his mapping revealed that even if not present in all businesses, slaves were nevertheless their main investment: some artisans prioritized the purchase of a slave over the purchase of tools of their trade, confident that such an acquisition would prove more profitable ${ }^{7}$.

The reason for this pattern of investment was the realization that the strong presence of slaves in the city devalued the fees artisans received for their labor, in particular for those working in public works ${ }^{8}$. The purchase and training of slaves were strategies used by many masters of trade, who could in this manner diversify their in-

6 LIMA, Carlos A. Artífices do Rio de Janeiro (1790-1818). Rio de Janeiro, Apicuri, 2008, pp. 79-98. 7 Idem, pp. 123-124.

8 Ibidem, pp. 109-122. 
come by profiting from the product of their slaves' skilled labor as well as by hiring their trained slaves to a third party. The advantages of this arrangement help explain the significant growth of the slave population in the city. This was only one aspect of urban slave labor, however. Hundreds of slaves also served the domestic needs of urban households or earned money in the streets, hiring out their labor throughout Rio de Janeiro. In this manner, and as the Marquis of Aguiar had emphasized, these slaves in the colonial capital had increasingly become "the arms on which all families rely".

It is important to note that the colonial state also employed slaves to carry out public works in the city. In 1799, for example, Joana Maria da Conceição and José Antônio Gonçalves presented two petitions to the municipal council requesting late payment for the wages of their slaves, who labored in the "works promoted by the Municipal Council". According to the owners, the governing body had committed to pay 100 réis a day for the work of each slave but had not yet fulfilled that payment ${ }^{9}$. The common practice of renting slaves was an important incentive to the purchase of captives, in particular for men and women of little means who could nevertheless acquire one to three slaves. That pattern that became increasingly more common throughout the first half of the nineteenth century.

During the final years of the eighteenth-century urban expansion in Rio de Janeiro and the growth of the city's population went hand in hand, it being impossible to pinpoint which one caused the other. These developments were indeed tightly interconnected in a colony that, between 1790 and 1801 (that is, during the administration of the Count of Resende) received more than 140,000 enslaved African ${ }^{10}$. If

9 AGCRJ. Códice 6.1.23. Documentos sobre a escravidão e mercadores de escravos, 1777-1831, pp. 297-300.

10 Cf.: Slave Trade Database. http://www.slavevoyages.org/tast/assessment/estimates.faces. It is important to note that 140,000 was the number of African slaves disembarked in the southeast region of the colony. During that same period, 1790-1801, Portuguese America received approximately 334,000 enslaved Africans, the majority of whom disembarked in the northeastern region of the colony, where sugar production experienced a revival in the aftermath of the Haitian Revolution. 
during that period the city of Rio de Janeiro experienced a territorial expansion thanks to landfills and the opening of streets, it was the result of the growing number of slaves performing these jobs.

The weaving of economic networks that supported the daily working of the City of Rio de Janeiro was inseparable from the use of enslaved labor, in particular of the natives of different regions and localities in Africa. The intensification of the transatlantic slave trade to the colonial Americas-where, since the mid-eighteenth century, Rio de Janeiro had become one of the main destinations ports-ensured that the city's economic, social, and cultural practices became increasingly intertwined with the massive arrival of enslaved Africans at the Valongo Wharf.

It is not surprising that Sir George Leonard Staunton-a botanist with the West India Company who visited the city in 1792-was struck not only by the prodigious number of Africans in the city but also by the different types of lives urban slaves and those working the fields experienced. Sir Staunton believed he had become familiar with the workings of "a place called Valongo"11 during the time he was in Rio de Janeiro: the market received around twenty thousand enslaved Africans every year. While the British secretary noted that three quarters of these captives were taken elsewhere, he observed that approximately five thousand remained in the city, "easily adjusting to their situation".

Four years later, in November of 1796, another British subject, George Vesson, recorded his impressions of what he had seen at Valongo: slaves "naked, exposed like cattle [...] who in a mixture of sadness, indignation and despair mirrored the group that amused themselves next door"12. The missionary was especially moved when confronted with an "old black man who, with his spent limbs, held a heavy load. He moaned a lot and it seemed like his back might break.

11 FRANÇA, J.M.C. Visões do Rio de Janeiro Colonial. Antologia de textos 1531-1800. Rio de Janeiro: EdUERJ/ José Olympio Editora, 1999, p. 203.

12 Idem. 
The black man advanced a few more steps with difficulty, cried for help and fell"'13. As he set out to help him, George Vesson was told by his interpreter that the slave "did not deserve a cent"14.

More than a possible abolitionist sentiment-a movement that was gaining ground among the British during the late eighteenth century-explains why an old and sick slave was not worth a cent, as the data in Table 1 reveals.

13 FRANÇA, J.M.C. Op. Cit., p. 242.

14 Idem. 
Table 1: The trade of Enslaved Africans to Rio de Janeiro and Portuguese AMERICA, 1791-1807

\begin{tabular}{|c|c|c|c|}
\hline Year & $\begin{array}{c}\text { Arrivals in the Port of } \\
\text { Rio de Janeiro }\end{array}$ & $\begin{array}{c}\text { Total Arrivals in } \\
\text { Portuguese America }\end{array}$ & $\begin{array}{c}\% \text { of Arrivals at the Port } \\
\text { of Rio de Janeiro/Total in } \\
\text { Portuguese America }\end{array}$ \\
\hline 1791 & 7478 & 21936 & $34 \%$ \\
\hline 1792 & 8456 & 30871 & $27 \%$ \\
\hline 1793 & 11096 & 31531 & $35 \%$ \\
\hline 1794 & 10225 & 31849 & $32 \%$ \\
\hline 1795 & 10640 & 33206 & $32 \%$ \\
\hline 1796 & 9876 & 26229 & $38 \%$ \\
\hline 1797 & 9267 & 30288 & $31 \%$ \\
\hline 1798 & 6780 & 23554 & $29 \%$ \\
\hline 1799 & 8857 & 26873 & $33 \%$ \\
\hline 1800 & 10368 & 25403 & $41 \%$ \\
\hline 1801 & 10011 & 29255 & $34 \%$ \\
\hline 1802 & 11343 & 32575 & $35 \%$ \\
\hline 1803 & 9722 & 29120 & $33 \%$ \\
\hline 1804 & 9075 & 34186 & $27 \%$ \\
\hline 1805 & 9921 & 33863 & $29 \%$ \\
\hline 1806 & 7111 & 34854 & $20 \%$ \\
\hline 1807 & 9689 & 35123 & $28 \%$ \\
\hline Total & 159.915 & 510.716 & $31,60 \%$ \\
\hline
\end{tabular}

Source: http://www.slavevoyages.org and FLORENTINO, M. Op. Cit., 1997, p. 51. 
Between the years of 1791 and 1807, nearly 160,000 enslaved Africans arrived in Rio de Janeiro. This number is almost equal to one third of all captives trafficked to Portuguese America in the same period and is evidence of the new Atlantic connections that elites in the city and captaincy of Rio de Janeiro established during the final decades of the eighteenth century. An important scholarly debate has related the increase of the slave trade to Rio de Janeiro to the expansion of agricultural production in the region. According to Jobson Arruda, the final fifteen years of the eighteenth century were marked by significant diversification and intensification in the production of foodstuff in the city's hinterland ${ }^{15}$. Arruda has argued that between 1796 and 1807, mostly in response to the incentives created by the Marquis of Pombal, the captaincy of Rio de Janeiro became one of the most important granaries of the Portuguese Empire, which in turn transformed the colonial capital into one of the most dynamic commercial entrepots of southern America, having become "the main redistribution pole of imported goods destined to the internal marke$t^{\prime \prime 16}$. Part of this argument has also been made by Pesavento, who has analyzed Rio de Janeiro's economic activities during the second half of the eighteenth century ${ }^{17}$.

The work of João Fragoso is also crucial to understanding how the production of foodstuff for the internal market and that activity's demand for enslaved hands ended up supporting not only the regional economy but also transforming the colonial capital into a dynamic commercial center with activities and networks that enabled men of lesser means to acquire enslaved Africans and profit from the trade in enslaved men and women. These venturesome men, as Fragoso called them, helped to create an important commercial elite

15 ARRUDA, J. "A época dos vice-reis fluminenses: o novo padrão de colonização, diversificação e integração econômica". In.: MAGALHÃES, A. BEZERRA, R. Os Vice-reis no Rio de Janeiro. 250 Anos. Rio de Janeiro: Museus Histórico Nacional, 2015, pp. 189-228.

16 Idem, p. 209.

17 PESAVENTO, F. “O colonial tardio e a economia do Rio de Janeiro na segunda metade do setecentos: $1750-$ 90". Estudos Econômicos, v. 42, n. 3, 2012. 
in Rio de Janeiro who, in turn, strengthened a series of social relationships with the political metropolitan elite, a situation that greatly influenced the choice of the city as the site of the Imperial Portuguese Court in 1808.

It is therefore clear that during the age of the viceroys the strong presence of slaves in urban activities was not just indicative of Rio de Janeiro's expanding commercial network but also of the growth and diversification of transoceanic commercial networks that were promoted by an increasingly stronger local economic elite. Slave labor was thus the foundation on which global relations (visible both within a local and transatlantic sphere) were established in the city of Rio de Janeiro.

\section{A miniaturized Lisbon in Little-Africa}

In the morning of March 4, 1813, O Patriota, one of the few circulating newspapers in Rio de Janeiro, headed its issue with a publication by Dr. Antonio Joaquim de Medeiros that aimed to understand the causes of the city's endemic diseases and insalubrity and assess a program proposed by the Municipal Council. Medeiros noted that, though diseases do not discriminate by "age, sex, or place of habitation", there was a clear difference between living in a city vulnerable to disease and epidemics because of its geographic location and the poor construction of its buildings and living in a well-organized, aired, and clean city. If the country's interior counted with urban centers that were well-structure, Rio de Janeiro, the doctor underscored, fell within the first category of cities. Hoping to better the urban apparatus of Rio de Janeiro and the lives of its inhabitants, Antonio de Medeiros addressed each of the issues raised by the Council's program and the attendant public works that were necessary to significantly improve the city ${ }^{18}$. It is important to note, however, a relevant 
detail in Medeiros' treatise: it had been written in 1798, fifteen years before its publication in the newspaper O Patriota.

Those intermittent fifteen years had been intensely experienced by residents of the city of Rio de Janeiro. In 1808, in response to a reordering of hegemonic forces in the Atlantic North-sparked by the continental blockage imposed by Napoleon Bonaparte after 1806-D. João of Portugal, the prince regent, made the unprecedented decision to transfer the capital of the Portuguese Empire to a colonial city: Rio de Janeiro.

Though previously conceived of by D. Rodrigo de Souza Coutinho, the transfer of the court to the colonial territory was only effectively implemented in 1807 and the arrival of the court in the City of Rio de Janeiro in March of 1808 marked an unparalleled development in the history of the Americas. In one strike Rio de Janeiro became the first and only New World city to host an overseas empire. To do justice to its new status, a series of urban transformations were pursued to elevate the city materially and symbolically to its role as center of power, control, and administration of the Portuguese world. The colonial capital had to take the place of an imperial metropole, which meant a transformation into what Schultz called a "tropical Versailles", an obvious allusion to the symbolic and effective role Versailles played in the French Empire ${ }^{19}$.

In this manner, the publication of Antonio de Medeiros's treatise was a reminder of the primordial meaning of the changes taking place at the Court: it was necessary to civilize Rio de Janeiro to ensure it matched its newfound status. In a certain way, the treatise published by $\mathrm{O}$ Patriota illustrated the herculean effort that Rio de Janeiro's urban transformation would require: fifteen years earlier, the future Imperial Court was considered to be an unhealthy, filthy, poorly aired city. But if it was not possible to change the city's location and natural environment, the manner through which this ur-

19 SCHULTZ, K. Versalhes Tropical. Império, Monarquia e a Corte Real portuguesa no Rio de Janeiro, 18081821. Rio de Janeiro: Civilização Brasileira, 2008. 
ban space was used could be changed. Such was the core notion that guided the many transformations implemented in the new Court: a giant urban reform held on American soil but one that mirrored the civilizing model embraced by the main European capitals.

These transformations were so monumental that many studies have examined the different dimensions of their implementation in the tropics. As Paulo Marins, Mireu Cavalcanti, and Kirsten Schultz have shown, changes to the urban perimeter dictated daily life in the city during the first years after the arrival of the court ${ }^{20}$. Swamps were drained to expand the urban limits of the city at a time when it counted only five parishes; the city expanded both in the direction of Botafogo-where families displaced by the Retirement Act moved to-as well as in the direction of the neighborhood of São Cristóvão, where the permanent residence of the royal family was being built. Other buildings were raised or modified to house the many administrative bodies that were "transmigrated", transforming Rio de Janeiro into a "miniaturized Lisbon"21.

It is important to remember that when the newspaper O Patriota published Antonio de Medeiros piece-perhaps to underscore the advances promoted by the urban reforms, perhaps to highlight how much more needed to be done to achieve the goals of civilizationchanges that were underway were made possible by three factors: the Urban Tenth tax, implemented in 1808 to assist with construction costs for the court; the city's administration, carried about by the Police Intendency through the notable figure of Paulo Fernandes

20 MARINS, P.C.G. Através da Rótula. Sociedade e Arquitetura Urbana no Brasil, séculos XVII a XX. São Paulo: Humanitas/FFLCH-USP, 2001. CAVALCANTI, N. Rio de Janeiro Setecentista. A vida e a construção da cidade da Invasão Francesa até a chegada da Corte. Rio de Janeiro: Jorge Zahar Editor, 2004. SCHULTZ, K. Op.Cit.

21 GOUVÊA, Maria de Fátima Silva. "As bases institucionais da construção da unidade dos poderes no Rio de Janeiro Joanino: administração e governabilidade no Império Luso-Brasileiro". In: JANCSÓ, I. (org). Independência: História e historiografia. São Paulo, HUCITEC/FAPESP, 2005, p.723. Andréa. Vida Política em tempo de crise: Rio de Janeiro (1808-1850). São Paulo: HUCITEC, 2006, pp. 51-77. 
Vianna (D. João's right hand man during the regency period ${ }^{22}$ ); and the intensified reliance on the labor of enslaved men and women.

Urban slaves had been responsible for great part of urban services in Rio de Janeiro since the time of the viceroys. As soon as John Luccock disembarked in Rio de Janeiro in 1808-immediately after the opening of the ports to friendly nations-he was struck by the number of Africans (enslaved and freed) who transited through the city's streets. For the traveler, the recently upgraded site of the Portuguese court looked more like the "heart of Africa". Throughout the ten years he lived in Portuguese America, the English man repeatedly witnessed the dynamic of Rio de Janeiro's urban slavery. According to him:

Any dignified house counted with slaves to whom one or more common arts had been taught and who not only worked their trade for the family to whom they belonged but were also hired out by their owners to others who were not as well-off. They could not earn much; in 1808 a worker was considered well-paid who made meia pacata, more or less one shilling, per day. But the influx of foreigners and the multiplication of demands in no time increased the value of work to an extravagant degree. The result was the formation of a new social class made of people who purchased slaves with the sole purpose of teaching them a useful art or trade to then sell them for a higher price or to hire out their talents and labor ${ }^{23}$.

Luccock's writings point to the massive use of slaves within the urban space, as well as the urban dynamic that demanded that a same slave learn two or more occupations, thus becoming property that was increasingly profitable to a potential owner. The emergence of this "new social class made of people who purchased slaves with the sole purpose of teaching them" was not accidental. Luccock was in Rio de Janeiro at a time when a large number of these learned sla-

22 SILVA, Maria Beatriz Nizza da. "A Intendência-Geral da Polícia: 1808-1821". In: Acervo. Rio de Janeiro, v.1, n.2, pp.137-151, jul - dez. 1986.

23 LUCCOCK, John. Notas sobre o Rio de Janeiro e partes meridionais do Brasil. São Paulo, EDUSP, 1975, p. 72. 
ves were employed in the urban works that aimed to reify the city's new social and political status; these were the slaves who drained swamps, paved streets, and constructed or reformed the buildings of the Court.

Table 2: The traffic of enslaved Africans to Rio de Janeiro and

Portuguese America, 1808-1815

\begin{tabular}{|c|c|c|c|}
\hline Year & $\begin{array}{c}\text { Arrivals in the Port of } \\
\text { Rio de Janeiro }\end{array}$ & $\begin{array}{c}\text { Total arrivals in } \\
\text { Portuguese America }\end{array}$ & $\begin{array}{c}\text { \% of arrivals in the port } \\
\text { of Rio de Janeiro/Total in } \\
\text { Portuguese America }\end{array}$ \\
\hline 1808 & 9602 & 25632 & $37 \%$ \\
\hline 1809 & 13171 & 32930 & $40 \%$ \\
\hline 1810 & 18677 & 53610 & $35 \%$ \\
\hline 1811 & 22520 & 42067 & $54 \%$ \\
\hline 1812 & 18270 & 46430 & $39 \%$ \\
\hline 1813 & 17280 & 41952 & $41 \%$ \\
\hline 1814 & 15300 & 43083 & $36 \%$ \\
\hline 1815 & 13300 & 40436 & $33 \%$ \\
\hline Total & 128.120 & 326.140 & $39,30 \%$ \\
\hline
\end{tabular}

Source: http://www.slavevoyages.org and FLORENTINO, M. Op. Cit., 1997, p. 51.

Table 2 illustrates the noticeable rise in the number of Africans trafficked to the port of Rio de Janeiro, as well as to the rest of Portuguese America, between 1808 and 1815. The increase in the percentage of arrivals at Valongo was linked to the new role the city of Rio de Janeiro then played within the larger Portuguese Empire. Beyond the use of enslaved people in the public works of the City-Court, the expansion of the city's commercial networks after 1808 (that is, after the opening of the ports) caused the rise in the use of a slave labor force that was very active around the wharves and throughout the 
city's main streets carrying merchandize, people, objects, and waste. In her pioneering and thorough work on urban slavery in Rio de Janeiro, Mary Karasch demonstrated that enslaved men and women, whether African or Brazilian born, did more than just domestic work, they carried out dozens of daily urban functions. Her findings have been further confirmed by the work of Marilene Nogueira and Luís Carlos Soares ${ }^{24}$.

The mobility and autonomy ensured by wage-earning-that is, urban slaves who earned income for their masters by hiring out their labor to third parties - as well as the practice of renting slave workers (often pursued even by government bodies, as argued above) helped to supply great part of the labor demands generated by the elevation of Rio de Janeiro to Imperial Court. The miniaturized Lisbon was not merely a "small Africa" as well: the labor force employed in public works and in the city's expanding commercial and port activities, enslaved African workers were also vital to the City's transformation in Court ${ }^{25}$.

Again, the traveler John Luccock-greatly influenced by the abolitionist perspective that spread throughout Great Britain-called attention to the practice that seemed to summarize the working of this slave City-Court: the white population's growing aversion to manual labor.

24 KARASCH, A vida dos Escravos no Rio de Janeiro (1808 - 1850). São Paulo: Cia. das Letras, 2000, 259291. SILVA, Marilene Nogueira. O Negro na Rua. A Nova face da escravidão. São Paulo: HUCITEC, 1988. SOARES, Luís Carlos. O "povo de Cam" na capital do Brasil: a escravidão urbana no Rio de Janeiro do século XIX. Rio de Janeiro: 7 LETRAS/FAPERJ, 2007, pp. 107-191.

25 Para um estudo mais aprofundado do uso de escravizados no processo de reformas urbanas do Rio de Janeiro a partir de 1808, ver: SANTOS, Ynaê. "Tornar-se Corte. Trabalho escravo e espaço urbano no Rio de Janeiro 1808-1815”. Revista de História Comparada, v.7, n, 1, pp. 262-292, 2013. 
White artisans added another insanity to that reality; they all believed themselves too noble to work in public and that it would be degrading to be seen carrying the smallest thing through the streets, even if it were the tools of their trade. The foolish pride and formalized presumptions that affected all Brazilian social classes reached within this category of men a singular level of absurdity and ridiculousness. One or two examples should illustrate well this character trait ${ }^{26}$.

Luccock correctly noted that the presumptions that affected all social classes were not limited to the urban boundaries of Rio de Janeiro. However, the quest for nobility was directly linked to the massive use of slave labor, a situation that created new demands and re-signified social belonging in a city that had become an imperial court: slavery was not only the foundation of Rio de Janeiro's economy, it also became a defining pillar for various social relations and ranks. Inevitably, these emerging relationships created a demand for more enslaved male and female hands, who were purchased not only to carry goods or to work in the city's wealthy and humble homes. Slavery, along with the expansion of the transatlantic slave trade, also helped to support an intricate social hierarchy that suited very well the preformistic nature of life in Court.

\section{The inevitable assembly of slaves}

It is undeniable that the growth of the slave population advantaged the workings of Rio de Janeiro. If in rural areas captives were the "hands and feet" of their masters, within the urban universe enslaved men and women made the city function. Not even the aspiration of becoming a tropical Versailles cooled the demand for slave labor in the city of Rio de Janeiro. Quite the opposite. The City-Court was afflicted by a potentially contradictory condition, its desire to be molded by civilizing standards and its increasing dependency on ensla-

26 LUCCOCK, J. Op. Cit., p. 82. 
ved Africans for all types of urban activities; that reality permeated Rio de Janeiro's urban dynamic for the next four decades.

As the Marquis of Aguiar noted, however, despite the many economic and social advantages slavery offered to urban life in Rio de Janeiro, it was necessary to ensure that the inevitable assembly of slaves did not become a source of disorder. The thousands of enslaved Africans who disembarked and lived in Rio de Janeiro originated from different parts of the African continent and possessed, therefore, distinct cultures. As a result, they re-signified the urban space in many different ways. A significant portion of urban slaves embraced the common local practice of joining a religious brotherhood, and those associations formed by populations considered to be of "color" became known as black brotherhoods.

Participating in a dynamic common to other urban centers in the colonial Americas, black brotherhoods received this name not only because of the color of their members' skin but also because of their devotion to equally black saints, such as Saint Elesbaan, Saint Ephigenia, Saint Benedict, and Our Lady of the Rosary. These organizations fulfilled the role of mutual aid associations and provided assistance to their members during their final moments, thus ensuring that passage to the next life could happen according to the norms prescribed by the Catholic Church ${ }^{27}$. Black brotherhoods also helped Africans recreate ties of belonging within the slave society through a Christian communion founded on a shared African identity. Not coincidentally, a large number of black brotherhoods were formed by men and women from different parts of the African Continent in eighteenth and nineteenth-century Rio de Janeiro, adding to existing brotherhoods whose members were black and mixed-descending men and women born in Portuguese America.

27 Sobre Irmandades escravas no Rio de Janeiro ver: SOARES, M.C. Devotos da Cor: Identidade Étnica, Religiosidade e escravidão no Rio de Janeiro do século XVIII. Rio de Janeiro: Civilização Brasileira, 2000. FARIA, Sheila S. de Castro. Sinhás Pretas, Damas Mercadoras. As pretas minas nas cidades do Rio de Janeiro e São João del Rey (1700-1850). Tese de Professor Titular apresentada junto do Departamento de História da UFF. Niterói, 2004. 
Much of the brotherhoods' activities aimed to improve the spiritual and material lives of their members-such as offer support for funerary processions and the creation of savings accounts destined to subsidize the purchase of freedom of members who were still enslaved. For these reasons, brotherhoods organized several festivities and celebrations-which were not always welcomed by governing authorities and the slave owning class-meant to reinforce ties of identity and belonging among their brothers of faith and claim spaces within the city. Yet, as the Marquis of Aguiar argued, it was not possible to prohibit all types of gatherings by the slave population: some gatherings, in particular those related to the brotherhoods, were sanctioned by the Catholic Church and were an intrinsic part of the public performances promoted by colonial America's urban theatrics-what Silvia Lara has referred to as the display of social hierarchies $^{28}$.

Various scholars have emphasized that even though black brotherhoods operated within the existing logic of the colonial slave society, their members' appropriation of that experience had great meaning. To be part of a congregation that could mobilize the legal means to release an individual from captivity was undoubtedly a great source of encouragement to numerous men and women who had been forced to recreate and re-signify symbols and meanings in a new world, completely unknown to them. If the rules of the game suppressed to some extent some struggles, they made it possible, on the other hand, for enslaved and freed people, African and Brazilian-born, to literally imprint in the space of the city fragments of their own history. This materialization of their existence ended up influencing the urban life, and in particular, the urban growth of Rio de Janeiro, a city (or yet, a colonial capital) that at the beginning of the nineteenth century counted as its religious seat a church built by and for blacks.

28 LARA, S. H. LARA, Silvia H. Fragmentos setecentistas. Escravidão, cultura e poder na América portuguesa. São Paulo: Cia. das Letras, 2007, p.125. 
In the period called the "time of the Viceroys" by the chronicler Luiz Edmundo, it was possible to witness every year:

The playful band of blacks coming down the Rosário street, near the street of Latoeiros and the path to the Terreiro do Paço, singing and dancing to the sound of casings, caxambus, checkers, marimbas, rattles and agogos, followed, cheered, and applauded by the youthful and talkative people that happily mixed in with and expanded the parade. One never saw so many blacks! They are blacks of all castes and rabbles, who spill out from surrounding alleys and lanes, attracted by the lure of the revelry: Congos and Moçambiques, Mojolos and Minas, Quilôas and Benguelas, Cabindas and Rebôlas, mixed in with disguised mulattos, the gipsy, and young black boys [...] No slave heeds his maters or obeys his owner during this minute of release and drunkenness. It is an insanity ${ }^{29}$ !

The scene described by Luiz Edmundo involved a black mob that, on a specific date, would claim the main thoroughfares of the city to celebrate in their own manner the symbolic coronation of African kings and queens. In his description, those streets, moreover, gave themselves up at least momentarily to outburst, drunkenness, and insanity. Catholicism offered some breathing room amidst slavery. It is important to note, however, that the omission of time references in Luiz de Edmundo's account homogenizes practices and identities forged in captivity. Whether in Rio de Janeiro or elsewhere in the New World, the lure of Catholic festivals could indeed attract "blacks of all castes and rabbles". But Moçambiques, Congos, Quilôas, Minas, and Benguelas did not view or experience slavery in exactly the same manner. First, because these groups were the product of reconfigured African identities formed in the Americas which, consequently, were subject to the vicissitudes of the colonial dynamic in which they were inserted. Second, because even though they may have shared the experience of captivity and the struggle for freedom, the "playful band of blacks" was never homogeneous. Seeking unity in a pheno- 
menon that was plural and diverse undermines our understanding of the complexity of urban slavery and of the special configuration of slave holding cities.

It would be challenging to understand why local authorities were constantly dealing with slave flight and the formation of quilombos (runaway slave communities) in the outskirts of the city if one assumed blacks in Rio de Janeiro (or any other colonial city for that matter) were a coherent group. Despite the importance brotherhoods and other mutual aid associations may have had to one's sense of belonging, the reconstructed identity slaves and freed people involved much more than such organizations; often, slaves did not associate themselves to brotherhoods, preferring to pursue other paths. Scholars have demonstrated that from the seventeenth century on, Municipal Councils and other governing bodies sought to define and distinguish forms of slave resistance ${ }^{30}$. It had become necessary to differentiate between a runaway slave and a quilombola (maroon), for example, or a mocambo and a quilombo. Only once that distinction was made was it possible to formulate punitive and preventive policies.

Since the administration of the Count of Bobadela, governor of the captaincy of Rio de Janeiro, regional authorities had been concerned with preventing the dangerous escalation of slave flight ${ }^{31}$. In 1793, chief-surgeon Manual Dias Lisboa sent a memo to the Municipal Council informing them that a bush-captain had captured his ru-

30 Dois trabalhos merecem destaque no que tange o estudo sobre a preocupação das autoridades coloniais no controle da fuga de escravos e na formação de quilombos: SCHWARTZ, S.B. "Mocambos, quilombos e Palmares: a resistência escrava no Brasil colonial”. In.: Estudos Econômicos, 17, número especial (1978), pp. 83-87. LARA, S.H. "Do singular ao plural. Palmares, capitães-do-mato e o governo dos escravos". In.: REIS, J.J. GOMES, F.S (Orgs.). Liberdade por um fio. História dos quilombos no Brasil. São Paulo: Cia. das Letras, 1996, pp. 81-109.

31 Kirsten Schultz cites a document produced by Paulo Fernandes Viana (General Police Intendent of Rio de Janeiro between 1808 e 1820) in which he references several measures taken by the Count of Bobadela to prevent flight and formation of quilombos in the city and captaincy of Rio de Janeiro. Cf. SCHULTZ, K. Op. Cit., p. 78. 
naway slave in the parish of Pilar ${ }^{32}$. The parish was one of many located in the lowlands along the rivers Iguaçu and Sarapuí, in the region of the Guanabara Bay. Since the mid eighteenth century the area was known for its production of foodstuff (much of which supplied the markets of Rio de Janeiro), sugar, and aguardente; it was also known as a haven for runaway slaves and quilombolas ${ }^{33}$.

Such documents increasingly found their way to the offices and desks of Municipal Councilmen; they all told the same story: runaway slaves, captured by private parties who requested an official license to act as a bush captain. And with each cycle of urban development, these captains had to cover more ground in search of runaway slaves. The most radical fights against slavery developed alongside the expansion of Rio de Janeiro. It would not be an exaggeration to say that resistance was proportional to the urban expansion and complexity that marked the city's history.

Indeed, after 1808, when the city of Rio de Janeiro was elevated to the status of Imperial court, slaves' efforts to appropriate the urban space increased, not only because the size of the slave population grew, but also because knowledge of how to navigate a slave city was disseminated more quickly among them. The thousands of men and women disembarked at Valongo and purchased by urban property holders were immediately introduced to the workings of the city. Throughout the nineteenth century, black brotherhoods continued to be key organizations in the socialization of many enslaved Africans, who were thus able to re-signify their identity beyond the general category of African, as well as use the social networks supported

32 AGCRJ. Códice 6.1.23. Documentos sobre a escravidão e mercadores de escravos, 1777-1831, p.295.

33 Cf.: GOMES, F.S. “Quilombos do Rio de Janeiro no século XIX.”. In.: REIS, J.J. GOMES, F.S. (Orgs.). Op. Cit., pp. 263-290. Nielson Bezerra, in his recent work, has demonstrated that since the "time of the Viceroys until the mid-nineteenth century, sugar, aguardente, and flour produced in this region of the Guanabara Bay were used as commercial currency in the trade local merchants established with West Africa. Cf. BEZERRA, N. Mosaicos da Escravidão: identidades africanas e conexões atlânticas do Recôncavo da Guanabara (17801840). Ph.D. Diss.: Instituto de História, Universidade Federal Fluminense, Niterói, 2010. 
by these brotherhoods in their search for freedom. This strategy was not the only one they adopted in their struggle for freedom, though.

As argued above, the greater mobility afforded urban slaves enabled them to claim the city for ends that went beyond their work; a common dynamic in slave centers of the Americas. It was not by chance that during the first years after the transfer of the Portuguese Court to Rio de Janeiro, local newspapers contained more announcements of slave flights than of slave sales ${ }^{34}$. These ads normally included the name of the runaway slave, physical descriptions, and some type of reward offered to those who found and returned the captive. Flávio Gomes's work on the formation of mocambos and quilombos in the outskirts of Rio de Janeiro suggests that often the greater mobility enjoyed by slaves in the urban space was interpreted by them (both Africans and Brazilian-born) as an extra-legal opportunity to escape captivity ${ }^{35}$. Flight often happened within the very space of the city, which itself offered hiding places to many runaway slaves ${ }^{36}$. The imperial court could temporarily serve as a type of mocambo to various captives, ensuring that Rio de Janeiro, while a space in which other transatlantic networks could be built, was also the "heart of Africa".

\section{Global because a slave holding order}

The Marquis of Aguiar's attempts to reassure the Count of Arcos regarding the uprising of thirty slaves in 1814 offers a window through which one can examine the different facets of urban slavery in Rio de Janeiro. To a certain extent, as the Marquis noted, if the demand for slave labor made assemblies of slaves inevitable, it was

34 A digital search of the newspaper collection of the National Library reveals a large number of runaway slave ads in issues of the Gazeta do Rio de Janeiro and O Patriota published between 1809 and 1815.

35 GOMES, F. Op. Cit. GOMES, F. História de Quilombos. Mocambos e histórias de senzalas no Rio de Janeiro, século XIX. São Paulo: Cia. das Letras, 2006.

36 SANTOS, Y. Além da Senzala. Arranjos escravos de moradia no Rio de Janeiro 1808-1850. São Paulo: HUCITEC, 2010. 
nevertheless important to understand which types of appropriation of urban space by slaves should be permitted and which should not. Often, the line between a meeting at a water fountain and a disorderly drumming was quite blurry. Consequently, government officials had to rely on careful attention and knowledge: without slaves the City-Court could not function, but with too many of them, the city's African heart could overpower the civilizing project of the Tropical Versailles.

When put into context, however, the Marquis of Aguiar's communication in 1814 was more than an experienced administrator's reminder to a fellow government official about the need for acumen when making decisions about bans and punishments imposed on the slave population in the most important city of the Portuguese Empire. In reality, the well-being of the slave City-Court also meant the implementation and projection into the future-as phrased by Felipe de Alencastro- of a choice that the Portuguese Empire had been made during the first years of the nineteenth century: the choice of slavery ${ }^{37}$.

Between 1791 and 1815, a period known as the age of revolutions, the Atlantic World underwent deep transformations. The independence of the United States in 1776, the implosion of the ancien regime in France, and the creation of the first American nation without slaves in Haiti (1791-1804) reoriented the structure of hegemonic forces in the Atlantic World, which in turn gave rise to the period of independence in the Iberian Americas ${ }^{38}$. The radicalism of the Haitian Revolution amplified the abolitionist debate and illustrated the possibility that the discomfort English men like Vessen felt when witnessing the treatment of an old and sick slave man in 1796 in Rio de Janeiro could become transnational politics. Slavery was increasingly

37 ALENCASTRO. L.F. A Vida Privada e a Ordem Privada no Império. In: ALENCASTRO, L.F. (org). História da Vida Privada no Brasil. Império: a corte e a modernidade nacional. Vol. 2. São Paulo: Cia. das Letras, 2004. 38 For a discussion of the age of revolutions and of the Portuguese Empire's choice of slavery, see: BLACKBURN, Robin. A queda do escravismo colonial: 1776-1848. Rio de Janeiro: Record, 2002. BERBEL, M. MARQUESE, R. PARRON, T. Escravidão e Política. Brasil e Cuba, 1790-1850. São Paulo: HUCITEC, 2010. 
challenged not only by the enslaved but also by the major economic power of the time, Great Britain.

More than the insurgent movements that unfolded in Rio de Janeiro in 1794, such as the Carioca Insurgency, the choice of the city to become the site of power within the Portuguese Empire was a product of the changes that reorganized the Atlantic World after 1791. Transformations effected during the age of revolutions reverberated and shaped the city's fate, transforming it after 1808 into the only American city to house the men and institutions that commanded a European Empire. The city that underwent numerous urban reforms in an attempt to match the European model of civilization also became an increasingly slave holding city.

As demonstrated, one of the main reasons for the growth in the number of slaves was the legacy of the time of the viceroys-a time when the city came to depend on slave labor to function. It was also related to the use of thousands of enslaved Africans and Brazilian-born slaves in the material and symbolic concretization of the $\mathrm{Ci}$ ty-Court project. Moreover, because Rio de Janeiro had become the locus of power of the entire Portuguese Empire, the internal dynamic of slavery in the city and the intensification of the trade in enslaved Africans was also a symptom of imperial rulers' commitment to slavery. A comparison between tables 1 and 2 reveals not only the rise in the absolute numbers of enslaved Africans disembarking in Portuguese America between 1791 and 1815 but also the proportional increase of enslaved African arrivals in Rio de Janeiro; a period when the consumption of enslaved bodies shocked foreign visitors. This double growth was not accidental.

Borrowing Carl Nightingale's methodological remarks on urban global history ${ }^{39}$, the case of Rio de Janeiro and of the intensification of its slave order represent the local scale of Portuguese commitment to the maintenance and expansion of slavery and was enacted by local

39 NIGHTINGALE, C. "World History needs more urban mess: a conversation with Carl Nightingale", Global Urban History Blog. August, 2016. 
Portuguese authorities and the slave owning class. Studies of the city after 1822 (when it became the capital of the independent Brazilian Empire) and until 1850, when the transatlantic slave trade to Brazil was finally abolished, unanimously show the fundamental importance of slavery to the city ${ }^{40}$.

But even before it became a court, the City of Rio de Janeiro was already a dynamic node connecting businesses and economic networks throughout the Atlantic (particularly within the South Atlantic), within which circulated a large range of foodstuff produced in the Fluminense hinterland, such as manioc flour and aguardente from the region of Iguaçu, as well as enslaved Africans of diverse origins. After 1808, the opening of its ports to foreign trade retraced Rio de Janeiro's commercial trade networks. Much of this new activity was dependent on the labor of or the trade in slaves.

The dynamic of Rio de Janeiro's slave order, if well-controlled as the Marquis of Aguiar argued, would allow enslaved Africans to re-signify the city's urban space in a safe way, without challenging the "invisible walls of the city", as Mary Karasch put it. Religious brotherhoods were not the only black institution that should be tolerated by the authorities and upstanding citizens: gatherings, musical and otherwise, and conversations between slaves need not compromise the order of the city and the slave order itself. The longevity of urban slavery in Rio de Janeiro throughout its period of transformation between 1791 and 1815 reveals the structural role slavery continuously played within the Portuguese Empire. The legacy of this period was reframed during the Brazilian Empire, to the extent that Rio de Janeiro, as the seat of power of the new nation, became the main slave city of the Americas during the mid-nineteenth century. The slave dimension of Rio de Janeiro ensured the city's transformation into an internalized metropole, completely implicated in the Atlantic transformations of the time. The city thus emerged as one of the large nodes linking global networks. 


\section{Bibliography}

ALENCASTRO. L.F. A Vida Privada e a Ordem Privada no Imperio. In: ALENCASTRO, L.F. (org). Historia da Vida Privada no Brasil. Imperio: a corte e a modernidade nacional. Vol. 2. Sao Paulo: Cia. das Letras, 2004.

ALEXANDRE, Valentim. Os sentidos do Imperio. Questao Nacional e Questao Colonial na Crise do Antigo Regime Português. Porto: Edicoes Afrontamento, 1993.

ARRUDA, J. “A epoca dos vice-reis fluminenses: o novo padrao de colonizacao, diversificacao e integracao economica". In.: MAGALHAES, A. BEZERRA, R. Os Vice-reis no Rio de Janeiro. 250 Anos. Rio de Janeiro: Museus Historico Nacional, 2015, pp. 189-228.

BERBEL, M. MARQUESE, R. PARRON, T. Escravidao e Politica. Brasil e Cuba, 1790-1850. Sao Paulo: HUCITEC, 2010.

BEZERRA, N. Mosaicos da Escravidao: identidades africanas e conexoes atlanticas do Reconcavo da Guanabara (1780-1840). Tese (Doutorado em Historia Social), Instituto de Historia, Universidade Federal Fluminense, Niteroi, 2010.

BLACKBURN, Robin. A queda do escravismo colonial: 1776-1848. Rio de Janeiro, Record, 2002

CAVALCANTI, N. Rio de Janeiro Setecentista. A vida e a construcao da cidade da Invasao Francesa ate a chegada da Corte. Rio de Janeiro: Jorge Zahar Editor, 2004.

DANTAS, M. HART, E. "Historical Aprroaches to researching the Global Urban". In: HARRISON, J. HOYLER, M. Doing Global Urban Research. Los Angeles: SAGE, 2018.

EDMUNDO, L. O Rio de Janeiro no Tempo dos Vice-reis. Rio de Janeiro: Editora Athenas, 1915.

ELIAS, Norbert. O Processo Civilizador. Uma Historia dos Costumes. Rio de Janeiro: Jorge Zahar Editor, 1990.

FLORENTINO, M. Em Costas Negras. Uma historia do trafico de escravos entre a Africa e Rio de Janeiro. Sao Paulo: Cia. das Letras, 1997

FRAGOSO, Joao Luis. Homens de Grossa Aventura. Acumulacao e Hierarquia na Praca Mercantil do Rio de Janeiro (1790-1830), Editora Arquivo Nacional, Rio de Janeiro, 1992, pp. 324.

FRANCA, J.M.C. Visoes do Rio de Janeiro Colonial. Antologia de textos 1531- 
1800. Rio de Janeiro: EdUERJ/ Jose Olympio Editora, 1900.

GOMES, F. Op. Cit. GOMES, F. Historia de Quilombos. Mocambos e historias de senzalas no Rio de Janeiro, seculo XIX. Sao Paulo: Cia. das Letras, 2006.

GOUVÊA, Maria de Fatima Silva. "As bases institucionais da construcao da unidade dos poderes no Rio de Janeiro Joanino: administracao e governabilidade no Imperio Luso-Brasileiro". In: JANCSO, I. (org). Independência: Historia e historiografia. Sao Paulo, HUCITEC/FAPESP: 2005.

HOLLOWAY, Thomas. Policia no Rio de Janeiro. Repressao e resistência numa cidade do seculo XIX. Rio de Janeiro,:Fundacao Getulio Vargas editora, 1997.

KARASCH, A vida dos Escravos no Rio de Janeiro (1808 - 1850). Sao Paulo: Cia. das Letras, 2000.

LARA, S. H. Fragmentos setecentistas. Escravidao, cultura e poder na America portuguesa. Sao Paulo: Cia. das Letras, 2007.

LARA, S.H. "Do singular ao plural. Palmares, capitaes-do-mato e o governo dos escravos". In.: REIS, J.J. GOMES, F.S (Orgs.). Liberdade por um fio. Historia dos quilombos no Brasil. Sao Paulo, Cia. das Letras, 1996.

LIMA, Carlos A. Artifices do Rio de Janeiro (1790-1818). Rio de Janeiro: Apicuri, 2008.

LUCCOCK, John. Notas sobre o Rio de Janeiro e partes meridionais do Brasil. Sao Paulo, EDUSP, 1975.

MARINS, P.C.G. Atraves da Rotula. Sociedade e Arquitetura Urbana no Brasil, seculos XVII a XX. Sao Paulo, Humanitas/FFLCH-USP, 2001.

MATTOS, Ilmar R. Construtores e Herdeiros. A trama dos interesses na construcao da unidade politica. Almanack Brasiliense n.1, pp. 8-26, 2005. Doi: https://doi.org/10.11606/issn.1808-8139.voi1p8-26.

MAWE, John. Viagens ao interior do Brasil: principalmente aos distritos de ouro diamantino. Rio de Janeiro: Zelto Valverdas, 1944.

NIGHTINGALE, C. "World History needs more urban mess: a conversation with Carl Nightingale", Global Urban History Blog. August, 2016.

NORONHA SANTOS, F. As freguesias do Rio antigo. Rio de Janeiro: Ed. O Cruzeiro, 1965.

PESAVENTO, F. "O colonial tardio e a economia do Rio de Janeiro na segunda metade do setecentos: 1750-90". Estudos Economicos, v. 42, n. 3, 
2012.

Praca Mercantil do Rio de Janeiro 1790-1830. Rio de Janeiro: Civilizacao Brasileira.

REIS, J.J. A Morte e uma festa. Ritos funebres e revolta popular no Brasil do seculo XIX. Sao Paulo: Cia. das Letras, 1991.

REIS, Joao Jose. GOMES, Flavio dos Santos. Repercussions of the Haitian Revolution in Brazil, 1791-1850. In.: GEGGUS, David P. FIERING, Norman (ed.) The World of the Haitian Revolution. Bloomington, Indiana University Press, 2009, pp. 284-313.

Rio de Janeiro 1790-1830. Rio de Janeiro: Civilizacao Brasileira, 1998.

RODRIGUES, J. De Costa a Costa. Escravos, marinheiros e intermediarios do trafico negreiro de Angola ao Rio de Janeiro (1780-1860). Sao Paulo: Cia. das Letras, 2005.

SANTOS, Ynaê Lopes. Alem da Senzala. Arranjos escravos de moradia no Rio de Janeiro (1808-1850). Sao Paulo: HUCITEC, 2010.

SANTOS, Ynaê. "Tornar-se Corte. Trabalho escravo e espaco urbano no Rio de Janeiro 1808-1815". Revista de Historia Comparada, v.7, n, 1, pp. 262292, 2013.

SCHULTZ, K. Versalhes Tropical. Imperio, Monarquia e a Corte Real portuguesa no Rio de Janeiro, 1808-1821. Rio de Janeiro: Civilizacao Brasileira, 2008.

SCHWARTZ, S.B. "Mocambos, quilombos e Palmares: a resistencia escrava no Brasil colonial”. In.: Estudos Economicos, 17, pp. 83-87, numero especial (1978).

SILVA, Maria Beatriz Nizza da. "A Intendência-Geral da Policia: 1808-1821". In: Acervo. Rio de Janeiro, v.1, n.2, pp.137-15, jul - dez. 1986.

SILVA, Marilene Nogueira. O Negro na Rua. A Nova face da escravidao. Sao Paulo: HUCITEC, 1988.

SOARES, Luis Carlos. O "povo de Cam" na capital do Brasil: a escravidao urbana no Rio de Janeiro do seculo XIX. Rio de Janeiro: 7 LETRAS/ FAPERJ, 2007.

SOARES, M.C. Devotos da Cor: Identidade Etnica, Religiosidade e escravidao no Rio de Janeiro do seculo XVIII. Rio de Janeiro: Civilizacao Brasileira, 2000. 
SOARES, M.C. Op. Cit. FARIA, Sheila S. de Castro. Sinhas Pretas, Damas Mercadoras. As pretas minas nas cidades do Rio de Janeiro e Sao Joao del Rey (1700-1850). Tese de Professor Titular apresentada junto do Departamento de Historia da UFF. Niteroi, 2004.

Dossier Rio de Janeiro and the Global City:

Compared stories of cities in the Modern Era of Globalization

Received in: 08/03/2019 - Approved in: 11/01/2020 